\title{
Serotonin and dopamine receptors in motivational and cognitive disturbances of schizophrenia
}

\author{
Tomiki Sumiyoshi ${ }^{1 *}$, Hiroshi Kunugi ${ }^{2}$ and Kazuyuki Nakagome ${ }^{3}$ \\ ${ }^{1}$ Department of Clinical Research Promotion, National Center Hospital, National Center of Neurology and Psychiatry, Tokyo, Japan \\ 2 Department of Mental Disorder Research, National Institute of Neuroscience, National Center of Neurology and Psychiatry, Tokyo, Japan \\ ${ }^{3}$ National Center Hospital, National Center of Neurology and Psychiatry, Tokyo, Japan
}

\section{Edited by:}

Bettina Bert, Freie Universiät Berlin, Germany

\section{Reviewed by:}

Doris Doudet, Aarhus University,

Aarhus University Hospital,

Denmark

Yukihiro Ohno, Osaka University of

Pharmaceutical Sciences, Japan

\section{*Correspondence:}

Tomiki Sumiyoshi, Department of Clinical Research Promotion,

National Center Hospital, National

Center of Neurology and Psychiatry,

4-1-1 Ogawahigashimachi, Kodaira,

Tokyo 187-8551, Japan

e-mail:sumiyot@ncnp.go.jp
Negative symptoms (e.g., decreased spontaneity, social withdrawal, blunt affect) and disturbances of cognitive function (e.g., several types of memory, attention, processing speed, executive function, fluency) provide a major determinant of long-term outcome in patients with schizophrenia. Specifically, motivation deficits, a type of negative symptoms, have been attracting interest as (1) a moderator of cognitive performance in schizophrenia and related disorders, and (2) a modulating factor of cognitive enhancers/remediation. These considerations suggest the need to clarify neurobiological substrates regulating motivation. Genetic studies indicate a role for the monoamine systems in motivation and key cognitive domains. For example, polymorphism of genes encoding catecholamine-O-methyltransferase, an enzyme catabolizing dopamine (DA), affects performance on tests of working memory and executive function in a phenotype (schizophrenia vs. healthy controls)-dependent fashion. On the other hand, motivation to maximize rewards has been shown to be influenced by other genes encoding DA-related substrates, such as DARPP-32 and DA-D 2 receptors. Serotonin (5-HT) receptors may also play a significant role in cognitive and motivational disabilities in psychoses and mood disorders. For example, mutant mice over-expressing $D_{2}$ receptors in the striatum, an animal model of schizophrenia, exhibit both decreased willingness to work for reward and up-regulation of $5-\mathrm{HT}_{2} \mathrm{C}$ receptors. Taken together, genetic predisposition related to $5-\mathrm{HT}$ receptors may mediate the diversity of incentive motivation that is impaired in patients receiving biological and/or psychosocial treatments. Thus, research into genetic and neurobiological measures of motivation, in association with 5-HT receptors, is likely to facilitate intervention into patients seeking better social consequences.

Keywords: serotonin, 5-HT receptors, motivation, cognition, schizophrenia, dopamine, negative symptoms, psychosis

\section{INTRODUCTION}

Disturbances of mental processes, including cognitive function (e.g., several types of memory, attention, processing speed, and executive function, fluency) and motivation characterize many of the psychiatric illnesses, such as schizophrenia, mood disorders, and substance abuse (Simpson et al., 2011; Choi et al., 2014; Sumiyoshi, in press). Recently, the development of biological (e.g., pharmacotherapy and brain stimulation) and psychosocial (e.g., cognitive rehabilitation) interventions is targeting social function/adaptation as an important outcome measure (Harvey et al., 2011; Leifker et al., 2011). In this context, negative symptoms (decreased spontaneity, social withdrawal, and blunt affect) and cognitive impairment provide a major determinant of long-term outcome. Specifically, motivation deficits have been attracting interest as a moderator of (1) cognitive performance in patients with schizophrenia and related disorders, and (2) beneficial influence of cognitive enhancers/remediation (Fervaha et al., 2014; Strauss et al., 2014). These considerations suggest the need to clarify neurobiological substrates regulating motivation for improving quality of life in a rational and effective manner.
We herein present a theory/hypothesis that the research into genetic and neurobiological measures of motivation, linked to serotonin (5-HT) receptors, would facilitate treatment of patients with schizophrenia or other psychiatric illnesses.

\section{MOTIVATIONAL DISTURBANCES IN SCHIZOPHRENIA}

Schizophrenia is characterized by a range of symptoms, e.g., positive symptoms (delusions, hallucinations, thought disorders), negative symptoms, mood symptoms, and cognitive impairment. Specifically, there is a suggestion that negative symptoms can be separated into two domains; (1) a motivational dimension, consisting of avolition, anhedonia, and asociality, and (2) a diminished expressivity dimension, consisting of restricted affect and alogia (Strauss et al., 2014). There is a general consensus that motivational disturbances may overlap some (e.g., anhedonia), but not all (e.g., blunt affect, alogia) aspects of negative symptoms. The former dimension has been considered to be of greater importance in terms of functional outcome, quality of life, and recovery from the disease (Strauss et al., 2014). Whether other aspects of symptomatology of schizophrenia (e.g., mood 
symptoms) may substantially affect motivation in patients or vulnerable people remains to be determined (Schlosser et al., 2014).

\section{DOPAMINE (DA) SYSTEMS GOVERNING MOTIVATION AND COGNITION}

The neural basis for intrinsic motivation has been an issue of extensive research. For example, activity of the anterior striatum and prefrontal cortex (PFC), measured by the functional MRI, has been shown to be associated with intrinsic motivation (Murayama et al., 2010). This line of anatomical evidence is consistent with genetic studies indicating a role for the monoamine systems in cognition and motivation, as discussed below.

The Val158Met polymorphism of the genes encoding catecholamine-O-methyltransferase (COMT), an enzyme catabolizing DA, affects performance on tests of working memory and executive function in a phenotype (schizophrenia vs. healthy controls)-dependent fashion (Egan et al., 2001). Thus, individuals with the val/val carriers in COMT show greater efficacy of the enzyme, leading to decreased DA levels in the PFC. The enzyme has also been suggested to mediate uncertainty-based exploration that is linked to DA levels in the PFC. For example, individuals with at least one met-allele show enhanced exploration compared to those with val/val genotype (Frank et al., 2007).

On the other hand, motivation to maximize rewards has been shown to be influenced by other DA-related genes expressed in the striatum/nucleus accumbens (NAc). Specifically, reward learning and negative reward avoidance are affected by genotypes of a polymorphism (rs907094. A/G) of the gene encoding DARPP32 (a protein required for synaptic plasticity and reward learning mediated by $\mathrm{DA}-\mathrm{D}_{1}$ receptors) and the $\mathrm{D}_{2}$ receptor (related to avoidance of negative outcomes), respectively (Frank et al., 2007; Klein et al., 2007). Thus, individuals with T/T genotype show greater expression of mRNA for the DARPP-32 gene, leading to greater performance to maximize rewards compared to C-allele carriers (reviewed in Frank et al., 2009). Similarly, T/T carriers of genes encoding $\mathrm{D}_{2}$ receptors are associated with greater density of these receptors in the striatum and greater likelihood to maximize rewards (Hirvonen et al., 2004; Frank et al., 2007). A recent study (Simpson et al., 2013) reported that overexpression of $\mathrm{D}_{3}$ receptors, a member of the $\mathrm{D}_{2}$ receptor family, in the striatum selectively impaired incentive motivation, as measured by an operant task.

The mechanisms by which DA receptors govern motivation and cognitive functions may involve timing perception. For example, genetically-engineered mice overexpressing D2 receptors in the striatum have been shown to elicit impaired working memory, behavioral flexibility and sensorimotor gating, i.e., behavioral abnormalities reminiscent of schizophrenia (Kellendonk et al., 2006). These model animals also demonstrate reduced motivation, as well as alteration of interval timing organization, as measured by the operant timing task (Drew et al., 2007). Further studies indicate that the impaired timing in these mutant mice mediates the ability of decreased motivation to worsen cognitive functions, including working memory and attention (Ward et al., 2009). These lines of evidence suggest a strategy for the intervention into motivational disturbances, in terms of biological and/or tailor-made treatments.

Figure 1 summarizes a concept about how genes encoding these DA-related substrates contribute to cognitive and motivational behaviors.

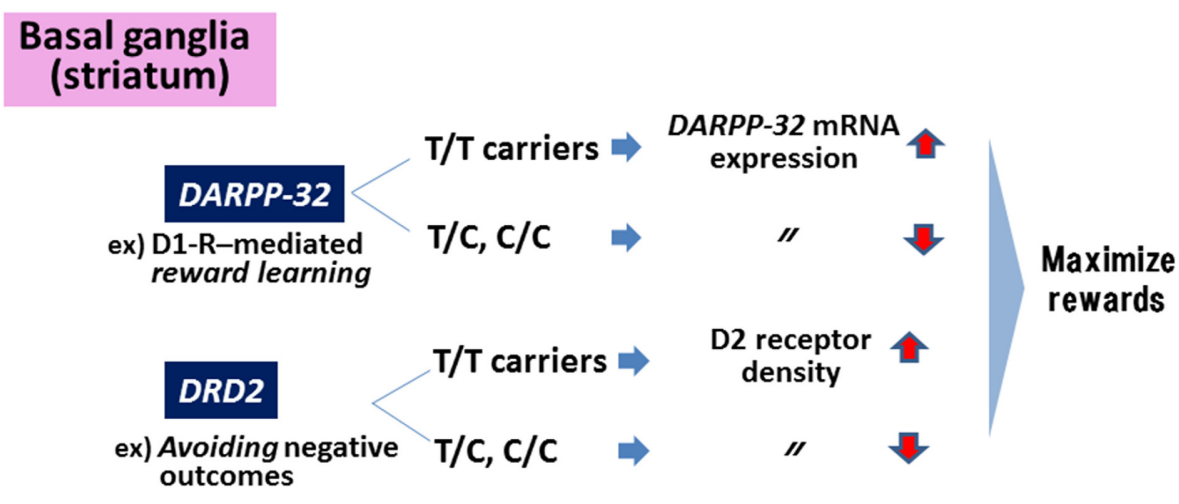

\section{Prefrontal cortex}

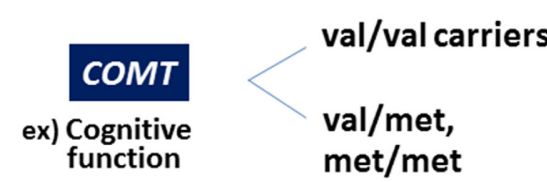

FIGURE 1 | Genes in the dopaminergic motivational system.

Polymorphisms of genes encoding DARPP-32 and dopamine (DA)- $\mathrm{D}_{2}$ receptors $(D R D 2)$ affect behaviors to maximize rewards, while the polymorphism in COMT are associated with uncertainty-based exploration. Information in the Figure was extracted from Frank et al. (2009). 


\section{5-HT RECEPTOR SUBTYPES IN MOTIVATION-RELATED BEHAVIORS}

5-HT receptors, e.g., $5-\mathrm{HT}_{1 \mathrm{~A}}, 5-\mathrm{HT}_{2 \mathrm{~A}}$, and $5-\mathrm{HT}_{2 \mathrm{C}}$ subtypes, may also play a role in cognitive and motivational disabilities in psychoses and mood disorders (Meltzer and Massey, 2011; NewmanTancredi and Albert, 2012; Ohno et al., 2012). For example, several antipsychotic and antidepressant drugs have been suggested to ameliorate negative symptoms and mood disturbances, partly through actions on $5-\mathrm{HT}_{1 \mathrm{~A}}$ and $5-\mathrm{HT}_{2 \mathrm{~A}}$ receptors (NewmanTancredi and Albert, 2012; Ohno et al., 2012; Sumiyoshi et al., 2013; Sumiyoshi, 2014). Clozapine, the prototype of atypical antipsychotic drugs, which is most effective in treating negative symptoms, may act as an inverse agonist on $5-\mathrm{HT}_{2} \mathrm{C}$ receptors (Meltzer and Massey, 2011).

Data from recent investigations support the contribution of 5-HT receptors to motivational behaviors. For example, mutant mice over-expressing $D_{2}$ receptors in the striatum, exhibit both decreased willingness to work for reward and up-regulation of 5- $\mathrm{HT}_{2 \mathrm{C}}$ receptors (Simpson et al., 2011). Furthermore, increased $\mathrm{D}_{1}, \mathrm{D}_{2}$ and $5-\mathrm{HT}_{2 \mathrm{C}}$ receptors co-exist in mice mis-expressing ADAR2, an RNA-editing enzyme, and these animals elicit altered expression of reward-related mRNAs in the brain (Akubuiro et al., 2013). Collectively, these observations indicate the importance of some 5-HT receptor subtypes, e.g., $5-\mathrm{HT}_{2 \mathrm{C}}$ receptors, in the pathophysiology and treatment of motivational disturbances associated with psychoses (Figure 2).
The role for $5-\mathrm{HT}_{2 \mathrm{C}}$ receptors in psychiatric symptoms relevant to functional outcome is also supported by observations in mice whose 5-HT-synthesizing enzyme (tryptophan hydroxyxlase-2) was genetically engineered (Del'Guidice et al., 2014). Thus, treatment with the $5-\mathrm{HT}_{2 \mathrm{C}}$ agonist $\mathrm{CP} 809,101$ ameliorated impairments in cognitive flexibility and reversal learning in these mutant animals (Del'Guidice et al., 2014).

As noted above, up-regulation of $5-\mathrm{HT}_{2 \mathrm{c}}$ receptors in the striatum may be associated with a decrease in incentive motivation (Simpson et al., 2011). Further, $5-\mathrm{HT}_{2 \mathrm{c}}$ receptors localized in DA and GABA neurons in the ventral tegmental area (VTA) also have been suggested to regulate motivation by modulating transmissions to NAc (Bubar et al., 2011) (Figure 2). It should be noted that a proportion of NAc-projecting VTA neurons may release both DA and GABA (Bubar et al., 2011). Altered balance in this complicated $5-\mathrm{HT}_{2 \mathrm{c}}$ receptor-associated network is postulated to cause reward-related disorders, such as schizophrenia, depression, and addiction (Bubar et al., 2011).

Other 5-HT receptor subtypes, such as $5-\mathrm{HT}_{1 \mathrm{~A}}$ and $5-\mathrm{HT}_{2 \mathrm{~A}}$ receptors, may directly or indirectly influence this neural system for motivational behaviors as well. For example, $5-\mathrm{HT}_{1 \mathrm{~A}}$ receptor gene promotor polymorphism (rs6295, C-1019G) has been associated with treatment effects on negative symptoms of schizophrenia (Reynolds et al., 2006). Figure 2 illustrates a putative neural network mediating motivational behaviors in relation to 5-HT receptors, which, together with

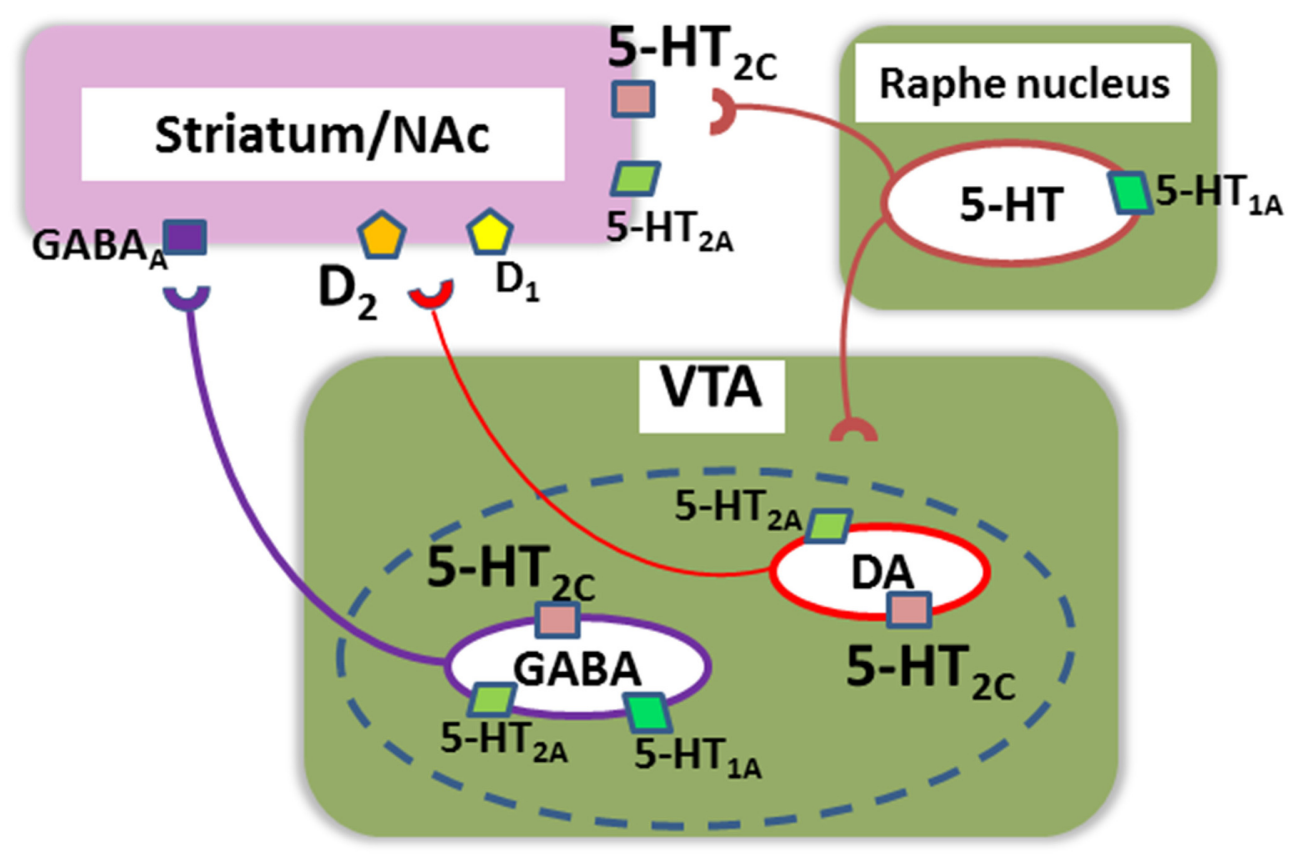

FIGURE 2 | A putative neural network mediating motivational behaviors in relation to serotonin (5-HT) receptors. (1) Up-regulation of $5-\mathrm{HT}_{2 \mathrm{c}}$ receptors in the nucleus accumbens (NAc)/striatum may be associated with a decrease in incentive motivation in mutant mice over-expressing dopamine $(D A)-D_{2}$ receptors in the striatum, an animal model of schizophrenia (Simpson et al., 2011). SB242084, a selective antagonist at these receptors, increases incentive motivation in these model mice. (2) $5-\mathrm{HT}_{2 \mathrm{c}}$ receptors localized in DA and GABA neurons in the ventral tegmental area (VTA) also affect motivation by modulating transmissions to $N A c$, including actions on $D_{1}$ and $D_{2}$ receptors (Bubar et al., 2011). The dotted line indicates that a proportion of NAc-projecting VTA neurons releases both DA and GABA (Bubar et al., 2011). (3) Other $5-\mathrm{HT}$ receptor subtypes, such as $5-\mathrm{HT}_{1} \mathrm{~A}$ and $5-\mathrm{HT}_{2 \mathrm{~A}}$, may also directly or indirectly regulate this neural system of motivational behaviors. 
Figure 1 (upper part), may suggest the contribution of DA-5-HT interactions.

\section{CLINICAL PERSPECTIVES AND FUTURE DIRECTIONS}

Based on the discussions so far, drugs acting on some 5-HT receptor subtypes, particularly, $5-\mathrm{HT}_{2} \mathrm{C}$ receptors, are likely to improve motivational deficits in individuals with schizophrenia. For example, SB242084, a selective antagonist at $5-\mathrm{HT}_{2 \mathrm{C}}$ receptors, has been shown to increase incentive motivation in mice over-expressing $\mathrm{D}_{2}$ receptors in the striatum, an animal model of schizophrenia (Simpson et al., 2011). By contrast, the 5- $\mathrm{HT}_{2 \mathrm{C}}$ receptor agonist CP809,101 has been demonstrated to enhance performance on some cognitive tasks in mice with decreased 5-HT synthesis (Del'Guidice et al., 2014). These preclinical observations warrant clinical studies of the effect of agents for specific 5-HT receptor subtypes, e.g., 5- $\mathrm{HT}_{2 \mathrm{C}}$ receptors, on motivational and cognitive disturbances. Specifically, it is important to see if such putative pro-motivation drugs will lead to improvement of functional outcome affected by cognitive function on which such compounds might act in variable directions.

In view of a possible influence of motivation on cognitive training, it may be interesting to determine if augmentation with pro-motivation compounds, e.g., 5- $\mathrm{HT}_{2 \mathrm{C}}$ agents, would provide additional merits for cognitive and functional outcome in patients with schizophrenia. Also, whether genetic variations regarding 5-HT and/or DA receptors affect motivational response to treatment with existing pharmacological or psychosocial interventions deserves further study.

In summary, genetic predisposition related to 5-HT and DA receptors may mediate the diversity of incentive motivation that is impaired in patients with schizophrenia. This concept is expected to facilitate rational treatment with biological and/or psychosocial tools to improve social consequences for people with psychiatric illnesses.

\section{ACKNOWLEDGMENTS}

This study was funded by grants-in-aid for Scientific Research from Japan Society for the Promotion of Science, Health (No. 26461761) and Labour Sciences Research Grants for Comprehensive Research on Disability, Health, and Welfare (H24-Seishin-Ippan-002 and H26-Seishin-Ippan-011). The authors thank Dr. Kazuyoshi Takeda for fruitful discussions.

\section{REFERENCES}

Akubuiro, A., Bridget Zimmerman, M., Boles Ponto, L. L., Walsh, S. A., Sunderland, J., McCormick, L., et al. (2013). Hyperactive hypothalamus, motivated and nondistractible chronic overeating in ADAR2 transgenic mice. Genes Brain Behav. 12, 311-322. doi: 10.1111/gbb.12020

Bubar, M. J., Stutz, S. J., and Cunningham, K. A. (2011). 5-HT(2C) receptors localize to dopamine and GABA neurons in the rat mesoaccumbens pathway. PLoS ONE 6:e20508. doi: 10.1371/journal.pone.0020508

Choi, J., Choi, K. H., Felice Reddy, L., and Fiszdon, J. M. (2014). Measuring motivation in schizophrenia: is a general state of motivation necessary for taskspecific motivation? Schizophr. Res. 153, 209-213. doi: 10.1016/j.schres.2014. 01.027

Del'Guidice, T., Lemay, F., Lemasson, M., Levasseur-Moreau, J., Manta, S., Etievant, A., et al. (2014). Stimulation of 5-HT2C receptors improves cognitive deficits induced by human tryptophan hydroxylase 2 loss of function mutation. Neuropsychopharmacology 39, 1125-1134. doi: 10.1038/npp.20 13.313
Drew, M. R., Simpson, E. H., Kellendonk, C., Herzberg, W. G., Lipatova, O., Fairhurst, S., et al. (2007). Transient overexpression of striatal $\mathrm{D}_{2}$ receptors impairs operant motivation and interval timing. J. Neurosci. 27, 7731-7739. doi: 10.1523/JNEUROSCI.1736-07.2007

Egan, M. F., Goldberg, T. E., Kolachana, B. S., Callicott, J. H., Mazzanti, C. M., Straub, R. E., et al. (2001). Effect of COMT Val108/158 Met genotype on frontal lobe function and risk for schizophrenia. Proc. Natl. Acad. Sci. U.S.A. 98, 6917-6922. doi: 10.1073/pnas.111134598

Fervaha, G., Agid, O., Foussias, G., and Remington, G. (2014). Effect of intrinsic motivation on cognitive performance in schizophrenia: a pilot study. Schizophr. Res. 152, 317-318. doi: 10.1016/j.schres.2013.11.037

Frank, M. J., Doll, B. B., Oas-Terpstra, J., and Moreno, F. (2009). Prefrontal and striatal dopaminergic genes predict individual differences in exploration and exploitation. Nat. Neurosci. 12, 1062-1068. doi: 10.1038/nn.2342

Frank, M. J., Moustafa, A. A., Haughey, H. M., Curran, T., and Hutchison, K. E. (2007). Genetic triple dissociation reveals multiple roles for dopamine in reinforcement learning. Proc. Natl. Acad. Sci. U.S.A. 104, 16311-16316. doi: 10.1073/pnas.0706111104

Harvey, P. D., Raykov, T., Twamley, E. W., Vella, L., Heaton, R. K., and Patterson, T. L. (2011). Validating the measurement of real-world functional outcomes: phase I results of the VALERO study. Am. J. Psychiatry 168, 1195-1201. doi: 10.1176/appi.ajp.2011.10121723

Hirvonen, M., Laakso, A., Nagren, K., Rinne, J. O., Pohjalainen, T., and Hietala, J. (2004). C957T polymorphism of the dopamine D2 receptor (DRD2) gene affects striatal DRD2 availability in vivo. Mol. Psychiatry 9, 1060-1061. doi: 10.1038/sj.mp.4001561

Kellendonk, C., Simpson, E. H., Polan, H. J., Malleret, G., Vronskaya, S., Winger, V., et al. (2006). Transient and selective overexpression of $\mathrm{D}_{2}$ receptors in the striatum causes persistent abnormalities in prefrontal cortex functioning. Neuron 16, 603-615. doi: 10.1016/j.neuron.2006.01.023

Klein, T. A., Neumann, J., Reuter, M., Hennig, J., Von Cramon, D. Y., and Ullsperger, M. (2007). Genetically determined differences in learning from errors. Science 318, 1642-1645. doi: 10.1126/science.1145044

Leifker, F. R., Patterson, T. L., Heaton, R. K., and Harvey, P. D. (2011). Validating measures of real-world outcome: the results of the VALERO expert survey and RAND panel. Schizophr. Bull. 37, 334-343. doi: 10.1093/schbul/ sbp044

Meltzer, H. Y., and Massey, B. W. (2011). The role of serotonin receptors in the action of atypical antipsychotic drugs. Curr. Opin. Pharmacol. 11, 59-67. doi: 10.1016/j.coph.2011.02.007

Murayama, K., Matsumoto, M., Izuma, K., and Matsumoto, K. (2010). Neural basis of the undermining effect of monetary reward on intrinsic motivation. Proc. Natl. Acad. Sci. U.S.A. 107, 20911-20916. doi: 10.1073/pnas.10133 05107

Newman-Tancredi, A., and Albert, P. R. (2012). "Gene polymorphism at serotonin 5-HT1A receptors: moving towards personalized medicine for psychosis and mood deficits?," in Schizophrenia Research: Recent Advances, ed T. Sumiyoshi (New York, NY: Nova Science Publishers), 337-358.

Ohno, Y., Tatara, A., Shimizu, S., and Sasa, M. (2012). "Management of cognitive impairments in schizophrenia: the therapeutic role of 5-HT receptors," in Schizophrenia Research: Recent Advances, ed T. Sumiyoshi (New York, NY: Nova Science Publishers), 321-335.

Reynolds, G. P., Arranz, B., Templeman, L. A., Fertuzinhos, S., and San, L. (2006). Effect of 5-HT1A receptor gene polymorphism on negative and depressive symptom response to antipsychotic treatment of drug-naive psychotic patients. Am. J. Psychiatry 163, 1826-1829. doi: 10.1176/appi.ajp.163. 10.1826

Schlosser, D. A., Fisher, M., Gard, D., Fulford, D., Loewy, R. L., and Vinogradov, S. (2014). Motivational deficits in individuals at-risk for psychosis and across the course of schizophrenia. Schizophr. Res. 158, 52-57. doi: 10.1016/j.schres.2014. 06.024

Simpson, E. H., Kellendonk, C., Ward, R. D., Richards, V., Lipatova, O., Fairhurst, S., et al. (2011). Pharmacologic rescue of motivational deficit in an animal model of the negative symptoms of schizophrenia. Biol. Psychiatry 69, 928-935. doi: 10.1016/j.biopsych.2011.01.012

Simpson, E. H., Winiger, V., Biezonski, D. K., Haq, I., Kandel, E. R., and Kellendonk, C. (2013). Selective overexpression of dopamine d3 receptors in the striatum disrupts motivation but not cognition. Biol. Psychiatry 76, 823-831. doi: 10.1016/j.biopsych.2013.11.023 
Strauss, G. P., Waltz, J. A., and Gold, J. M. (2014). A review of reward processing and motivational impairment in schizophrenia. Schizophr. Bull. 40(Suppl. 2), S107-S116. doi: 10.1093/schbul/sbt197

Sumiyoshi, T. (in press). "Cognitive impairment in schizophrenia," in Encyclopedia of Psychopharmacology, 2nd Edn., eds I. Stolerman and L. H. Price (New York, NY: Springer), 1-7.

Sumiyoshi, T. (2014). Serotonin(1A) receptors in the action of aripiprazole. J. Clin. Psychopharmacol. 34, 396-397. doi: 10.1097/JCP.00000000000 00135

Sumiyoshi, T., Higuchi, Y., and Uehara, T. (2013). Neural basis for the ability of atypical antipsychotic drugs to improve cognition in schizophrenia. Front. Behav. Neurosci. 7:140. doi: 10.3389/fnbeh.2013.00140

Ward, R. D., Kellendonk, C., Simpson, E. H., Lipatova, O., Drew, M. R., Fairhurst, S., et al. (2009). Impaired timing precision produced by striatal D2 receptor overexpression is mediated by cognitive and motivational deficits. Behav. Neurosci. 123, 720-730. doi: 10.1037/a00 16503
Conflict of Interest Statement: The authors declare that the research was conducted in the absence of any commercial or financial relationships that could be construed as a potential conflict of interest.

Received: 23 July 2014; paper pending published: 28 September 2014; accepted: 18 November 2014; published online: 04 December 2014.

Citation: Sumiyoshi T, Kunugi H and Nakagome K (2014) Serotonin and dopamine receptors in motivational and cognitive disturbances of schizophrenia. Front. Neurosci. 8:395. doi: 10.3389/fnins.2014.00395

This article was submitted to Neuropharmacology, a section of the journal Frontiers in Neuroscience.

Copyright (c) 2014 Sumiyoshi, Kunugi and Nakagome. This is an open-access article distributed under the terms of the Creative Commons Attribution License (CC BY).

The use, distribution or reproduction in other forums is permitted, provided the original author(s) or licensor are credited and that the original publication in this journal is cited, in accordance with accepted academic practice. No use, distribution or reproduction is permitted which does not comply with these terms. 